\title{
HARDENING OF PARTS OF AGRICULTURAL MACHINERY WITH LASER MICROALLOYING
}

\author{
Alexander Pastukhov, Olga Sharaya, Nataliia Vodolazskaya, Alexan Minasyan \\ Belgorod State Agricultural University named after V. Gorin, Russia \\ pastukhov_ag@mail.ru,sharay61@mail.ru,vnv26@bk.ru, alikmun@yandex.ru
}

\begin{abstract}
The work presents researches in the microstructure of surface layers after laser hardening of C 45, laser processing with pre-printed slip coatings, as well as after the complex treatment, which includes plasma welding and laser processing. The studies established the presence on the surface after modification three zones: the zone of welding - transition zone with a pronounced needle-like fine structure and framework with a ferritepearlite structure. Electron microprobe analysis carried out on the scanning electron microscope TESCAN VEGA/LSU showed the presence in the melted layer increased content of tungsten in the sample with HS 18; tungsten, vanadium and molybdenum in the sample with HS 5-6, as well as tungsten, cobalt, chromium and vanadium in the sample with HS 13-0-4-5. As the distance from the deposited layer in the transition zone and the original C 45 there were observed the disappearance of peaks of the alloying elements and the increase of the content of iron, silicon and carbon. The results of measurement of microhardness for all studied samples showed that the microhardness reached the maximum values of up to $16000 \mathrm{HV}$, when welding with powder HS 18 and the height of the laser head $l=15 \mathrm{~mm}$; to $14720 \mathrm{MPa}$, when welding with powder HS 5-6 and the height of the laser head $l=20 \mathrm{~mm}$; and $22400 \mathrm{HV}$, when welding with powder HS 13-0-4-5 and the height of the laser head $l=15 \mathrm{~mm}$, which exceeds the microhardness of $\mathrm{C} 45$ in the initial 8-11 times and 3-4 times in comparison with laser treatment of C 45 with no preliminary welding. The presence of a dense layer with high microhardness indicates that the method of plasma micro alloying and subsequent laser treatment can be used to restore worn parts with a sharp increase in the microhardness of the surface, and to process new parts for their surface hardening. The choice of a particular composition for plasma deposition and subsequent regimes of laser treatment depends on the specific operating conditions of the modified products of $\mathrm{C} 45$.
\end{abstract}

Keywords: laser, steel, modifying, microstructure, hardening.

\section{Introduction}

At the present-day stage of technology development the problem of developing in agricultural mechanical engineering materials for parts and products with qualitatively new properties becomes more urgent that can be achieved due to technological processes of hardening treatment [1-3].

Among hardening technologies a special place is taken by physical-and-chemical methods of affecting the material surface, as its state defines mainly the level of hardness and operational properties of the machine parts. In most cases it is the product surface that is subjected to increased wear, contact loads and in a larger extent breaks due to corrosion.

Based on the literature data and modeling the processes of hardening treatment for products of steel and iron, it was established that the most prospective is chemical-thermal treatment, as well as surface hardening using highly-concentrated energy sources, i.e. laser and plasma treatment [4-11].

At present fundamental and applied developments in the field of physics and chemistry are widely used in metallurgy for developing different technologies of the surface hardening treatment.

However, in spite of rather wide use of different methods of product treatment in industry, nowadays there has not yet been developed a unified theory of surface hardening, and the works done are mainly of private character. This is explained by the complexity of physical-and-chemical processes that take place on the surface at high-temperature interaction with saturating environments, phase and structural transformations at the diffusion stage, the process kinetics.

With the aim of developing a technology of surface hardening in the present work there are studied the most prospective methods of modifying iron and steel product surfaces: laser microalloying.

\section{Materials and methods}

The research of the problem of different functional purpose products reliability and durability showed that at present it is impossible to solve this problem due to the use of expensive high-alloy steels because of economic inexpediency. In this connection there becomes very urgent the way of 
increasing the durability of products made of carbon steels due to thermal hardening and microalloying their working surfaces using laser radiation.

In the work studies of laser alloying processes were carried out. On the sample surface of $\mathrm{C} 45$ there were preliminarily placed plasters of "W-V-Cr" system, as a binder liquid glass was used. The samples were treated with their surface burning by continuous radiation of a powerful $\mathrm{CO}_{2}$-laser "HEBR-2500". The treatment modes were selected in such a way that there was not a strong burning of the surface. On the first group of samples laser treatment was carried out with the parameters presented in Table 1.

Table 1

\section{Laser treatment parameters}

\begin{tabular}{|l|c|c|c|c|c|}
\hline Laser radiation power, $P, \mathrm{~W}$ & \multicolumn{5}{|c|}{500} \\
\hline Material treatment speed, $v, \mathrm{rpm}$ & \multicolumn{5}{|c|}{520} \\
\hline Laser head height, $l, \mathrm{~mm}$ & 1 & 5 & 10 & 12 & 15 \\
\hline
\end{tabular}

The results of the preliminary testing showed that the surface burning was good but there existed one structural feature of the laser "HEBR-2500": an objective lens that is located in the head is aircooled for preventing the object breaking. The air flow blows the melted layer of metal and leads to forming of a groove of $1,5 \mathrm{~mm}$ depth on the surface. The head height increasing over the sample alongside with increasing the radiation power led to increasing the dimensions of the zone treated that is not always desirable, that is why in the further experiments the treatment speed was increased. The parameters of treating the second group of samples are presented in Table 3. In the second group on the first three samples there was also observed forming of grooves, but with the head height over 10 $\mathrm{mm}$ there was no melt spread.

In practice for obtaining a surface without reflow there are often absorbing coverings used. The radiation wave length from the laser "HEBR-2500", namely $10,6 \cdot 10^{-3} \mathrm{~mm}$, is almost absorbed by aluminum oxide $\mathrm{Al}_{2} \mathrm{O}_{3}$. The samples of the third group were covered with an absorbing covering based on aluminum oxide mixed with lacquer $4 \mathrm{C}$. The third group treatment parameters are presented in Table 2.

Table 2

\section{Laser treatment parameters}

\begin{tabular}{|l|c|c|c|c|c|}
\hline Laser radiation power, $P, \mathrm{~W}$ & \multicolumn{5}{|c|}{500} \\
\hline Material treatment speed, $v, \mathrm{rpm}$ & \multicolumn{5}{|c|}{1400} \\
\hline Laser head height, $l, \mathrm{~mm}$ & 1 & 5 & 9 & 12 & 15 \\
\hline
\end{tabular}

It is characteristic that at the small height of the laser head $l=1$ and $5 \mathrm{~mm}$ there were burnt grooves observed, but their maximum depth was only $0.4 \mathrm{~mm}$. In the rest cases the radiation burnt the covering, but the surface was not deformed, i.e. there was no zone of burning.

Studying of the structure and phase composition of the materials was carried out with use of a raster electronic microscope of TESCAN VEGA//LSU, the power dispersive microanalyzer of the INCA Energy-350 system of OXFORD Instruments (England) production, x-ray diffractometers "DRON-3, DRON-6". Surface hardness after the laser and combined processing was estimated on Vikkersa on the Galileo ISOSCAN device, microhardness on the PMT-3 device.

\section{Results and discussion}

The analysis of the problem of different functional purpose product reliability and durability showed that at present it is impossible to solve this problem due to the use of expensive high-alloy steels because of economic inexpediency. In this connection the way of increasing the durability of products made of carbon steels due to thermal hardening and micro-alloying their working surfaces using laser radiation becomes very urgent.

Micro-X-ray-spectral analysis was carried out on the raster electronic microscope TESCAN VEGA//LSU with the system of micro-analysis INCA of OXFORD Instruments (England) production. The general view of $\mathrm{C} 45$ microstructure after laser alloying with placing "W-V-Cr" composition by the slip process is presented in Figure 1. 


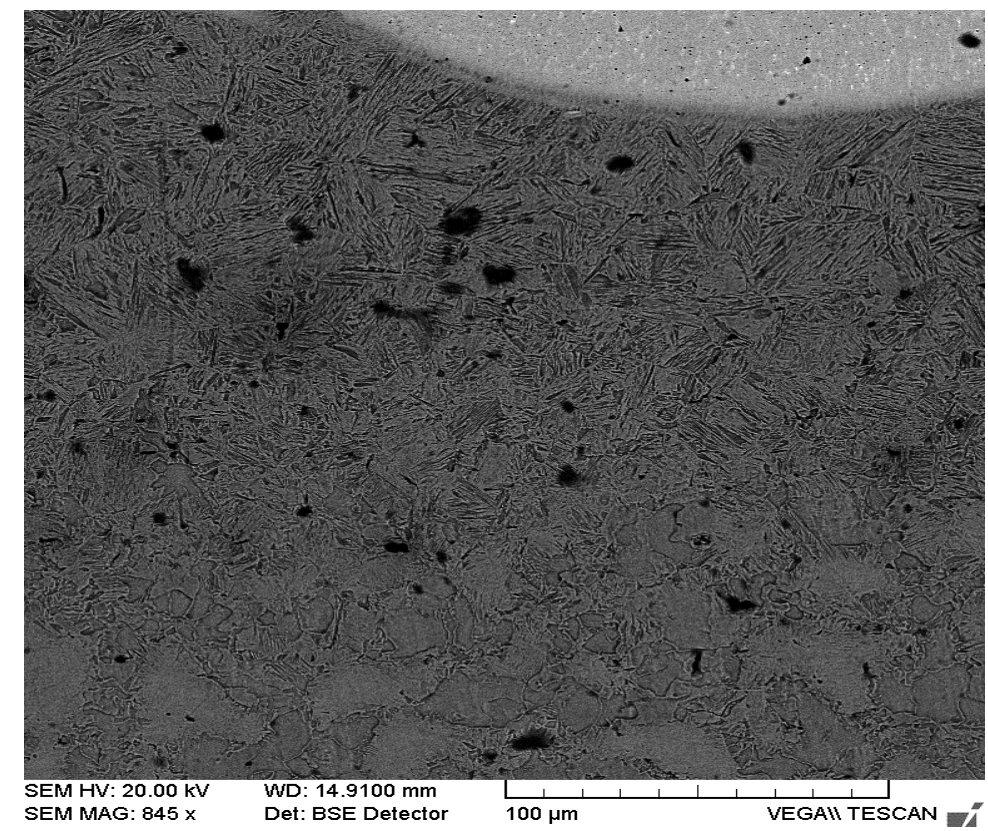

\section{Fig. 1. General view of $\mathbf{C} 45$ microstructure after laser alloying with placing "W-V-Cr" composition}

In Figure 2 there is shown the micro-X-ray-spectral analysis of the padded layer. X-ray-structural studying of laser alloying zones with the system "W-V-Cr" showed that the hardened layer is a solid solution of the alloying elements in ferrite.

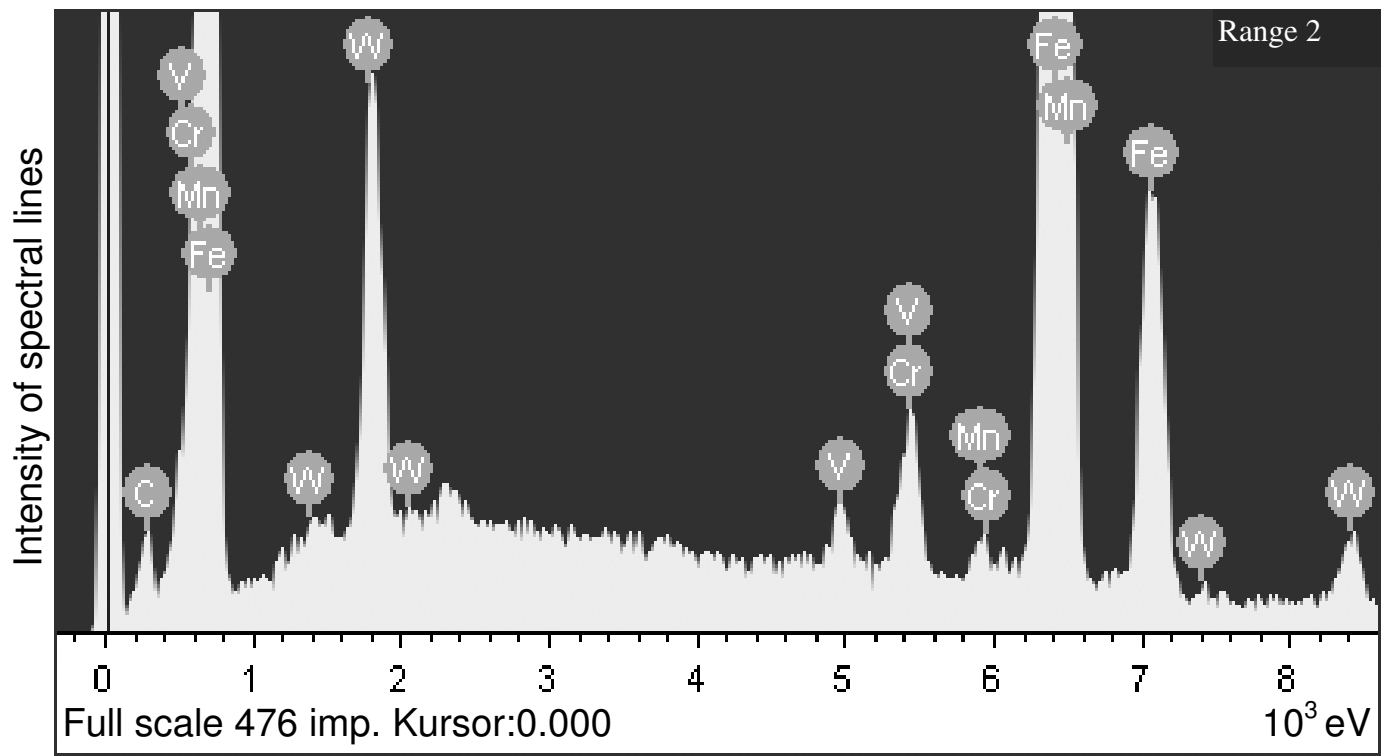

Fig. 2. Micro-X-ray-spectral analysis of padded layer of $\mathbf{C} 45$ after laser alloying with placing "W-V-Cr" composition

Metallographic analysis established that when alloying in the constant mode of radiation at high speeds of the laser beam moving, in the surface layer there forms a weakly etching structure of martensite. Laser alloying with optimal speeds of the beam moving relating to the treated surface $\left(v=10-20 \mathrm{~mm} \cdot \mathrm{s}^{-1}\right)$ leads to forming a very-finely grained structure of alloyed ferrite, besides, the largest part of the volume is occupied with equal-axed celled grains.

With advancing to the border with the matrix the grains acquire pie-column form, oriented to maximal heat removal.

A more effective way of formation of the alloyed layer before laser processing is plasma-jet hardfacing. We will in detail stop on a C 45 weld deposit powder HS 18. 
Results of the microstructural and microx-ray spectral analysis of the samples are presented in Figures 3, 4, 5 and in Table 3.

Processing of a range of samples with plasma weld deposit powder HS 18 and subsequent laser processing

\begin{tabular}{|c|c|c|}
\hline Element & Weight, \% & Atomic, \% \\
\hline $\mathrm{C}, \mathrm{K}$ & 5.07 & 21.42 \\
\hline $\mathrm{V}, \mathrm{K}$ & 0.83 & 0.83 \\
\hline $\mathrm{Cr}, \mathrm{K}$ & 2.20 & 2.14 \\
\hline $\mathrm{Mn}, \mathrm{K}$ & 0.00 & 0.00 \\
\hline $\mathrm{Fe}, \mathrm{K}$ & 79.48 & 72.18 \\
\hline $\mathrm{W}, \mathrm{M}$ & 12.42 & 3.43 \\
\hline Total & \multicolumn{2}{|c|}{100} \\
\hline
\end{tabular}

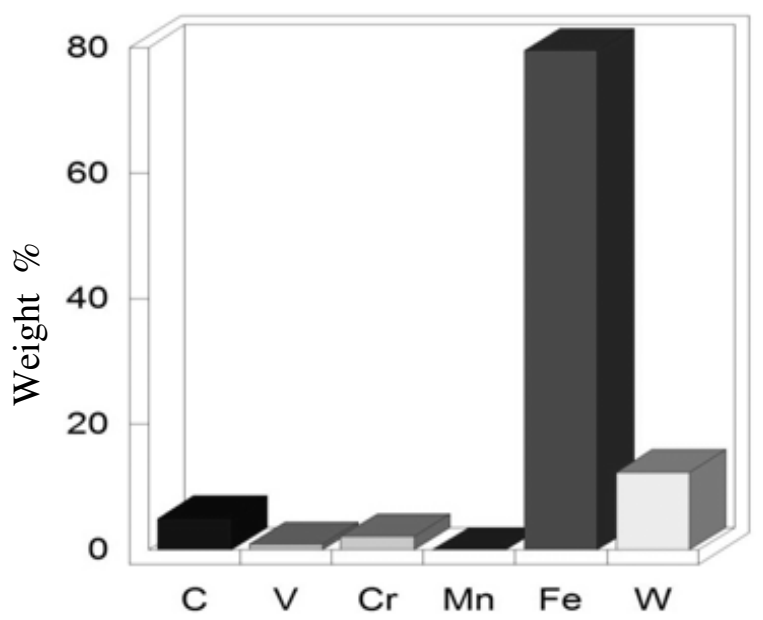

Fig. 3. Qantitative characteristic of distribution of element in range 1

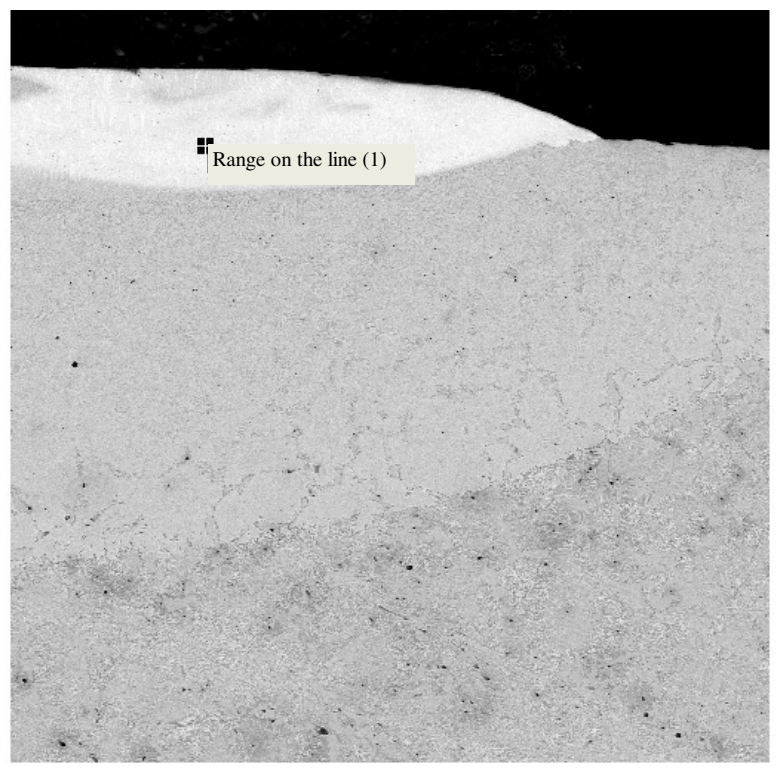

Fig. 4. Microstructure of built-up layer with indication of range 1 


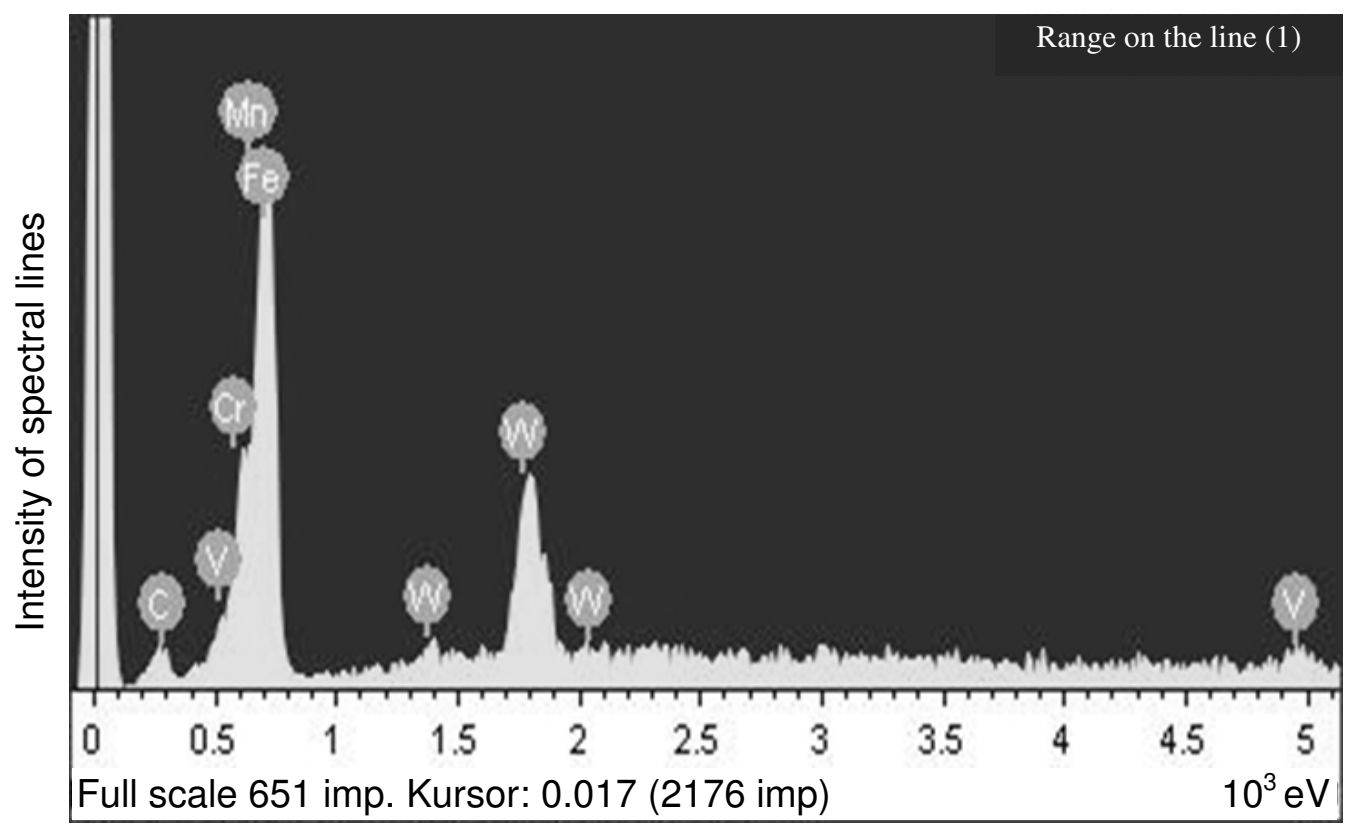

Fig. 5. Distribution of elements in sample layer with plasma-jet hard-facing powder HS 18 and subsequent laser processing

The alloying elements in the nonequilibrium conditions caused by laser processing not only alloy the layer, but also exert noticeable impact on the transitional zone, which after superfast cooling consists of fine-needled martensite and extends to more considerable distances deep into the samples, thereby creating conditions for smooth transition to the metal ferrite-pearlitic base of C 45 and strong coupling of the built-up layer with the metal base.

The structural changes arising when forming the built-up layer were followed by a sharp change of the properties. The microhardness analysis of the samples after plasma microalloying was carried out on the PMT-3 device. The results of distribution of microhardness on the depth of the samples of C 45 with the systems of alloying: "tungsten" (HS 18), at various modes of laser processing are presented in Figure 6.

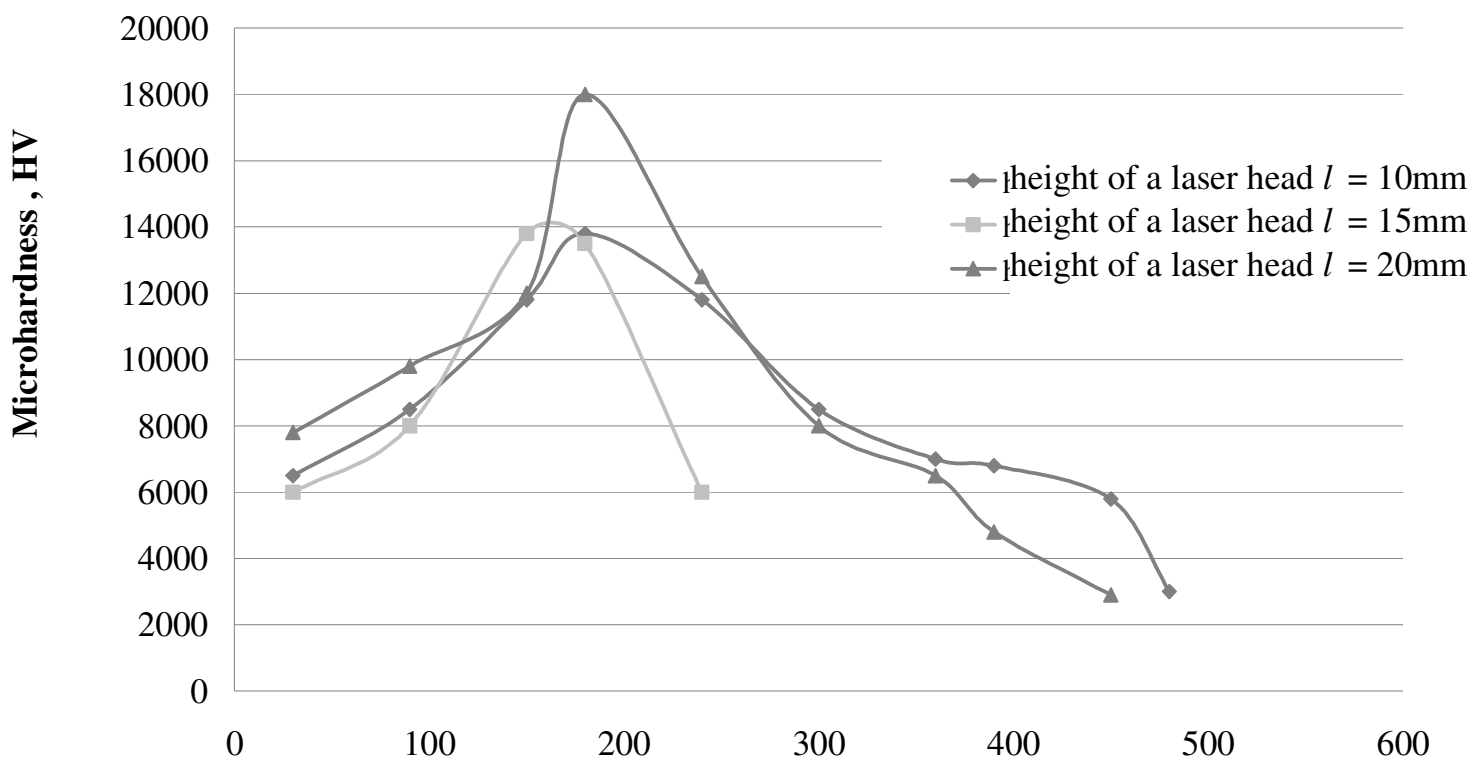

Distance from a surface of $h, 10^{-3} \mathrm{~mm}$

Fig. 6. Distribution of microhardness of samples from $\mathrm{C} 45$ with preliminary plasma-jet hardfacing powder HS 18 and subsequent laser processing at speed of scanning of beam $V=1400 \mathrm{~mm} \cdot \mathrm{m}^{-1}$ 
Wear test in the conditions of sliding friction was carried out on the friction machine SMC-2 under the loads 25-1800 N. As working environments oil I-70A and air were used. The test was carried out at the constant sliding speed $1.3 \mathrm{~m} \cdot \mathrm{s}^{-1}$ at the room temperature. As a result, wear resistance of the micro-alloyed layers increased 3-4 times as compared to the surfaces not treated with laser radiation.

\section{Conclusions}

1. At industrial continuous $\mathrm{CO}_{2}$ - laser "HEBR-2500" was treated preliminarily placed by the system "W-V-Cr" coverings and the modes of laser treatment for the final forming of the surface layer were defined. The microstructure of $\mathrm{C} 45$, the phase composition and element distribution in the padded layers were studied on the raster electronic microscope TESCAN VEGA//LSU with the system of micro-analysis INCA of OXFORD Instruments (England) production. The mechanism of forming a structure in the surface layer was studied.

2. Microhardness and wear resistance of the samples were measured studied in different zones of hardening. There was shown 6-7 times increase of microhardness as compared to the initial values of C 45. Wear resistance after laser alloying increased 3-4 times. A technology of laser microalloying parts made of $\mathrm{C} 45$ was developed.

\section{References}

[1] Пантелеенко Ф.И., Оковитый В.А., Девойно О.Г. и др. Методика разработки комбинированных упрочняющих технологических процессов (A technique of development of the combined strengthening technological processes). The strengthening technologies and coverings, №10, 2010, pp. 36 - 38. (In Russian).

[2] Шарая О.А., Водолазская Н. В. Упрочнение деталей модельной оснастки (Hardening of details of the model equipment). Works of the international scientific and practical conference "Integration of science, education and production - a basis of implementation of the Plan of the nation", part 4, June 21-23, 2017, Karaganda, Kazakhstan, pp. 96 - 98. (In Kazakhstan).

[3] Issagulov A.Z., Kvon S.S., Kulikov V.Y., etc. Cr - Ni system alloys impact on durability value. Metalurgija. Sisak, Yugoslavia, T. 53, № 4, 2014, pp. 621-623.

[4] Григорьянц А.Г. Основы лазерной обработки материалов (Bases of laser processing of materials). Moscow: Mechanical engineering, 1989. 301p. (In Russian).

[5] Ломаев Г.В., Харанжевский Е.В. Упрочняющая обработка поверхности методом высокоскоростной лазерной перекристаллизации (The strengthening processing of a surface by method of high-speed laser recrystallization). Metallurgical science and heat treatment of metals, №3, 2002, pp.27-32. (In Russian).

[6] Бровер А.В. Структурные особенности процесса поверхностного упрочнения стали концентрированными потоками энергии (Structural features of process of superficial hardening became the concentrated energy streams). Materials science, №9, 2005, pp. 18-23. (In Russian).

[7] Галенко П.К., Харанжевский Е.В., Данилов Д.А. Высокоскоростная кристаллизация конструкционной стали при лазерной обработке поверхности (High-speed crystallization of structural steel at laser processing of a surface). Journal of technical physics, vol. 72, № 5, 2002, pp. 48-55. (In Russian).

[8] Пастухов А.Г., Шарая О А., Минасян А. Г., Водолазская Н. В. Технология лазерного микролегирования углеродистых сталей для упрочения деталей сельскохозяйственных машин (Technology of laser microalloying carbonaceous steels for consolidation of details of farm vehicles). Innovations in agrarian and industrial complex: problems and prospects, № 2 (10), 2016, pp. 34-47. (In Russian).

[9] Lysonkova I., Novotny J., Cais J., etc. Effect of addition of nanoparticles $\mathrm{TiO}_{2}$ into PTFE coating. Proceedings of 16th International scientific conference "Engineering for rural development", May 24-26, 2017, Jelgava, Latvia, pp. 26-30.

[10]L.X. Pan et al., Processing and Stability of Ultrafine Grained Structures in Some Microalloy Steels, Materials Science Forum, Vols. 500-501, 2005, pp. 363-370.

[11] W. R. Maruda et al., Influence of Minimum Quantity Cooling Lubrication (MQCL) on Chip Formation Zone Factors and Shearing Force in Turning AISI 1045 Steel, Applied Mechanics and Materials, Vol. 657, 2014, pp. 43-47. 